\title{
The Potential of Using Renewable Energy Sources in Poland Taking into Account the Economic and Ecological Conditions
}

\author{
Mariusz Niekurzak (D) \\ Faculty of Management, AGH University of Science and Technology, 30-059 Krakow, Poland; \\ mniekurz@zarz.agh.edu.pl
}

check for

updates

Citation: Niekurzak, M. The Potential of Using Renewable Energy Sources in Poland Taking into Account the Economic and Ecological Conditions. Energies 2021, 14, 7525. https://doi.org/10.3390/en14227525

Academic Editors: Wei-Hsin Chen, Aristotle T. Ubando, Chih-Che Chueh and Liwen Jin

Received: 2 November 2021

Accepted: 8 November 2021

Published: 11 November 2021

Publisher's Note: MDPI stays neutral with regard to jurisdictional claims in published maps and institutional affiliations.

Copyright: (C) 2021 by the author. Licensee MDPI, Basel, Switzerland. This article is an open access article distributed under the terms and conditions of the Creative Commons Attribution (CC BY) license (https:/ / creativecommons.org/licenses/by/ $4.0 /)$.

\begin{abstract}
The aim of the manuscript was to present the collective results of research on the profitability of using various renewable sources in Poland with the greatest development potential. In the paper, the economic parameters of various investment projects were determined and calculated, i.e., Net Capital Value (NPV), Internal Rate of Return (IRR) and the Period of Return on Invested Capital (PBT). The economic assessment of the use of RES technologies was supplemented with the assessment of environmental benefits. The ecological criterion adopted in the study was the assessment of the potential and costs of reducing greenhouse gas emissions as a result of replacing fossil fuels with renewable energy technologies. On the basis of the constructed economic model to assess the profitability of investments, it has been shown that the analyzed projects will start to bring, depending on their type and technical specification, measurable economic benefits in the form of a reduction in the amount of energy purchased on an annual basis and environmental benefits in the form of reduction of carbon dioxide emissions to the atmosphere. Moreover, the calculations show a high potential for the use of certain renewable sources in Poland, which contributes to the fulfillment of energy and emission obligations towards the EU. The analyzes and research of the Polish energy market with the use of the presented models have shown that the project is fully economically justified and will allow investors to make a rational decision on the appropriate selection of a specific renewable energy source for their investment. The presented economic models to assess the profitability of investments in renewable energy sources can be successfully used in other countries and can also be a starting point for a discussion about the direction of energy development. Due to the lack of collective, original and up-to-date research on the domestic market, the manuscript provides the reader with the necessary knowledge regarding the legitimacy of using renewable energy sources, investment and environmental profitability.
\end{abstract}

Keywords: renewable energy sources; solar energy; wind energy; ecology; environmental protection

\section{Introduction}

Energy has been an important influential factor in the economic and political policies and bilateral relations of countries and in the formation of legal rules as soon as it began to occupy its irrevocable place in human life. There are different types of energy-a diversity that was not present when energy was first discovered-due to the reduction of typical energy resources and due to environmental concerns today. The countries which have sources of energy elaborate some energy policies and implement them. Some countries with limited possibilities in terms of sources of energy, on the other hand, develop new roles for themselves in energy and play important roles in leading world policy in order to not fall out of the world order [1]. Environmental fossil fuels were the source of as much as $83 \%$ of the energy consumed in Poland in 2020 . This value is five times greater than the value of energy obtained from RES. This puts Poland in the infamous first place in Europe in terms of obtaining energy from fossil fuels. As a result, electricity generated in Poland is also the most "dirty" within the EU: to produce $1 \mathrm{kWh}$ of energy, you need to emit $724 \mathrm{~g}$ of $\mathrm{CO}_{2}$, which is three times more than the European average [2-5]. It is 
worth noting that in 2020 Poland was one of the largest coal producers in Europe, which entails numerous negative effects on our planet, including contribution to the ozone hole, biological life imbalance, soil and air pollution [6-10]. This is one of the reasons why the air in Poland is one of the most polluted in Europe. According to the "Clean Heat" Report from 2020 prepared by the Ministry of Climate, solid fuel-fired coal boilers are still the most common heat source used in Poland and account for approximately $42 \%$ of suspended dust [11-16]. The authors in [17-22] broadly describe the environmental impact of $\mathrm{CO}_{2}$ emissions. Moreover, the overarching goal of the $\mathrm{EU}$ is to achieve $32 \%$ of energy from renewable sources by the end of 2030 and to reduce greenhouse gas emissions from $40 \%$ to $55 \%[16,23,24]$. In order to achieve the energy and emission targets imposed by the EU in Poland, it is necessary to consider the development of renewable energy technologies within the energy sector as a priority. Poland must enter the path of the "green revolution", i.e., energy transformation, and start rebuilding its economy and energy sector towards renewable energy sources as soon as possible. It is dictated by the result of many factors. In addition to the obligations obliging Poland to further increase the share of renewable energy in the overall EU economy from $11 \%$ to $15 \%$ by the end of 2022, the issue of record prices of $\mathrm{CO}_{2}$ emission allowances should also change the approach to the economics of energy production $[6,7,15]$. The transformation of the national economy towards renewable energy will require overcoming numerous challenges in order to obtain a stable electricity supply. Without a long-term energy policy, the Polish energy sector will face a drift and the risk of economically unsuccessful investments in renewable energy.

To avoid catastrophic climate change, the world must achieve zero carbon emissions in all sectors of the economy by 2050. To this end, according to Directive 2009/28/EC [2], EU Member States should gradually increase the share of energy from their renewable sources, both in total energy consumption and in the transport sector. The problem related to $\mathrm{CO}_{2}$ emissions in transport has been widely described in publications [25-36]. In Poland, despite production of energy from renewable sources is growing every year, the country's main source is still conventional energy sources. The studies of climate change models carried out so far accurately predict global warming [37]. According to one of them, published in 2020 by NASA, the average global temperature in the world will increase by about $2.5^{\circ} \mathrm{C}$ only by the end of the century [38-40]. It should be emphasized here that as a result of human-induced climate change, the average surface temperature of the Earth has already increased by more than $1^{\circ} \mathrm{C}$ above the pre-industrial level [41]. Therefore, if greenhouse gas emissions are not reduced quickly, as indicated by the portal Science about Climate, in the 2030s, the temperature increase may reach $1.5^{\circ} \mathrm{C}$, and by 2100 , it will exceed $4^{\circ} \mathrm{C}$, which will be devastating for humanity, catastrophic and difficult to estimate consequences. Unfortunately, the decades-long trend of increasing greenhouse gas emissions continues and, in 2020, reached a record level of $59.1 \mathrm{GtCO}_{2}$, the vast majority of which is carbon dioxide from the combustion of fossil fuels [42-44].

In 2015, in the Paris Agreement, to which 190 countries (including EU member states) joined, the nations of the world agreed on a common goal: "Limiting the increase in the average surface temperature of the Earth to well below $2{ }^{\circ} \mathrm{C}$ above the pre-industrial level and continuing efforts to limit the increase in temperature up to $1.5^{\circ} \mathrm{C}^{\prime \prime}[45,46]$. It was the first ever universal, legally-binding climate agreement. The agreement stipulates that all countries, starting from 2020, will announce voluntary greenhouse gas emission reduction targets, and these targets will not only be revised but will also be increased every five years [47]. This is evidenced by, for example, the examples of undisputed leaders in the European RES sector, such as the Scandinavian countries, which cover most of the energy demand from renewable energy sources. Despite the fact that Asia is the leader in the development of renewable energy, which is currently responsible for more than half of the capacity connected in the previous year, as can be seen, the Old Continent also focuses more and more on green energy. Even the COVID-19 pandemic in Europe did not prevent the member states from taking these actions. The last report of the European Commission states that in the first quarter of 2021, renewable energy sources recorded their record 
result, which was a $40 \%$ share in the European energy mix. In line with the objectives of the EU climate and energy package, the share of renewable energy in the final energy consumption for Poland by 2021 should be $15 \%$, and by 2030, 23\% [43,44]. According to the Ministry of Climate, the EU target for RES share in the energy mix set by 2021 may not be met by Poland until 2022 [47-50]. However, despite this, the power of renewable energy sources in our country is increasing with each subsequent year (only in 2019 this increase was $9 \times$ higher than in 2018). At the end of 2020, RES installations in Poland had a total capacity of 9979.2 MW. At the moment, according to the data of the Energy Regulatory Office, at the end of 2020, the most renewable energy in Poland was produced by installations using wind energy (6347.2 MW), solar energy (887.5 MW) and installations using biomass (1512.9 MW). Next were hydropower installations (976.1 MW) and biogas installations (255.7 MW). These data represent the share of individual energy sources in electricity production in Poland at the end of 2020: hard coal $46 \%$, lignite $24 \%$, natural gas $10 \%$, wind $10 \%$, biomass / biogas $5 \%$, water $2 \%$, other $2 \%$. Thus, in total, the most emissive coal sources accounted for $70 \%$ of domestic electricity generation and $14 \%$ for renewable energy [51-53].

The energy transformation is currently the main goal of Polish politics. The government is focusing on building a new energy system with a capacity of about 40 GW by 2040, which will largely be green energy, which, according to the IAE Agency, opens the way to full decarbonization both in the EU countries and in Poland. In order to meet the energy and emission targets for Poland, more extensive measures should be taken, aimed at, inter alia, encourage investors to invest in renewable energy. Poland, wanting to catch up in this area, prepared and introduced an amendment to the law at the end of 2019, which creates the possibility of great interest in energy production by prosumers, which currently include selected entrepreneurs. The amendment to the act on renewable energy sources introduced a number of significant changes to the support system for electricity generated from renewable energy sources, including extending the definition of a prosumer to enterprises for which energy production is not the main object of economic activity and gives them the opportunity to take advantage of the discount system; energy billing in longer billing cycles; no need to prepare a construction design for the smallest micro-installations up to $6.5 \mathrm{~kW}$ [54]; the possibility of locating micro-installations in areas that have a purpose other than production, the entry into force of the so-called thermo-modernization relief in personal income tax, etc. Thanks to the relief, natural persons can deduct expenses incurred, inter alia, from the income tax base for renewable energy installations with accessories, as well as their assembly. In addition, the Polish government introduced a number of subsidies, such as My Electricity, Clean Air, Stop Smog or Energy Plus, which are to enable financial support for entities investing in renewable energy.

Bearing these aspects in mind, the author's aim is to present the important role of renewable energy technologies in the national pro-ecological cycle. Due to the lack of collective, original and up-to-date research on the domestic market, the manuscript provides the reader with the necessary knowledge regarding the legitimacy of using renewable energy sources, investment and environmental profitability. Renewable sources with the highest potential for use in Poland were analyzed. Based on the analyzes and research performed, they were compared in terms of various aspects: legal, technical, climatic and economic. The obtained conclusions will help a potential investor make a wellbalanced decision on the proper selection of a specific RES for his investment. Moreover, the obtained results may constitute a starting point for a discussion on the direction of development of the Polish energy sector.

\section{Materials and Methods}

The work is of a research and analytical nature, which is devoted to the assessment of the economic efficiency of renewable energy technologies (RES) and the assessment of the environmental benefits of using these technologies. The key to deriving credible system conclusions in the proposed study was the microeconomic assessment of RES 
technologies, the generalized results which allowed to calculate the marginal costs of reducing greenhouse gas emissions due to replacing fossil fuels with energy from renewable sources. The research nature of the work resulted from the need to obtain original, reliable and proven input data for the model of comparative economic evaluation of various RES technologies. The most popular renewable energy technologies in Poland were used for the analysis, for which surveys were carried out directly at the installation users. The data was collected using a questionnaire method using specially prepared description forms of representative operating installations for various technologies and with the use of the database of the European Renewable Energy Center on investments made in the renewable energy sector. The collected data were verified by interviews with users and, in justified cases, a visit. The tool for carrying out comparative economic and financial studies based on the obtained input data was a consistent and uniform methodology for data analysis and evaluation of results with regards to all sources and technologies. This methodology was based on the concepts of discounted inflows and outflows defined in the English-language literature as cash flows. This method normally leads to the determination of such economic parameters of an investment project as net capital value (NPV), Internal Rate of Return (IRR) and period of return on invested capital (PBT). The variable parameters considered in assessing the profitability of investments in renewable energy were the level of investment subsidies, the rate of preferential interest on investment loans, the accelerated depreciation rate, the VAT rate on equipment, a reduced rate or exemptions from income tax and a possible subsidy to the price of energy sold by an independent supplier of renewable energy to the grid. The economic assessment of the use of RES technologies was supplemented with the assessment of environmental benefits. The ecological evaluation criterion adopted in the study was the assessment of the potential and costs of reducing greenhouse gas emissions as a result of replacing fossil fuels with renewable energy technologies.

\subsection{Return on Investment Analyzes}

The developed calculation sheet made it possible to evaluate the profitability of any investment, assuming specific data on the amount of investment expenditure, method of financing, operating costs, tax burden, method of depreciation and revenues over a period of up to 20 years. The following indicators were used to assess profitability: repayment period, net present value of future cash flows (NPV), Internal Rate of Return (IRR). The basic element of the analysis is the pro forma profit and loss account and the statement of financial flows. The financial result in a given year is influenced by revenues from the sale of electricity or heat, operating costs, which include annual costs of inspections, repairs, additional service charges, other repair costs expressed as a percentage of capital expenditure incurred for commissioning, depreciation of the entire investment, interest on loan repayment, income tax. The obtained net profit was the basis for determining the cash surplus in a given year according to the formula:

$N F=$ net profit + depreciation + additional payments to the price (from the state budget)—repayment of the capital part of the loan

Cash surplus is shown with a plus (+) sign, and negative with a minus (-). Capital expenditures in year " 0 " are included as expenditure, i.e., with a minus sign $(-)$.

The accumulated cash flows, i.e., capital expenditures in year " 0 " plus subsequent flows in the following years, were used to determine the first of the profitability ratios, i.e., the repayment period. The repayment period is understood to be the number of years expected to recover the original investment. The payback calculation consisted in adding up the cash flows of the investment project and checking when the sum is 0 , i.e., the financial surpluses will cover the capital expenditure (and any negative cash flows from the initial years when the investment is not necessarily profitable). The shorter the repayment period, the more favorable the investment should be assessed.

The second method of economic appraisal of the investment project that was used in the calculations is the present value of the future net cash flow (NPV). This method is based on the discounted cash flow methodology. NPV calculations were performed according to 
the following principle: the present value (i.e., for year " 0 ") of cash flows discounted in each period according to the cost of capital (discount rate) was determined; the obtained sum of discounted cash flows was defined as the NPV of the project and if the NPV was positive - the project was accepted, if negative-it should be rejected. The NPV equation on the basis of which the calculations were made is as follows $[55,56]$ :

$$
\mathrm{NPV}=\sum_{t=0}^{n} \frac{C F_{t}}{(1+k)^{t}}
$$

where: $C F$-expected cash flow in the period $t(t$-subsequent years: $0,1,2 \ldots), k$-the assumed capital cost of the project.

An NPV of zero means that the cash flow is exactly enough to pay off your invested capital and bring you the required rate of return on capital. When an investment (project) has a positive NPV-then the cash flow provides additional income. The NPV method is supplemented by the IRR method (internal rate of return) defined as a discount rate which equates the present value of the expected cash flows with the present value of the expected costs (capital expenditures). Calculations were made on the basis of the formula [54-56]:

$$
\sum_{t=0}^{n} \frac{C F_{t}}{(1+\mathrm{IRR})^{t}}=0
$$

Note that Equation (2) is the NPV equation, solved for a specific discount rate that makes NPV equal to zero. In the NPV method, the discount rate $\mathrm{k}$ is determined and the surplus value (i.e., NPV) is calculated, in the IRR method the fixed NPV is zero, and the IRR (discount rate) value is calculated, which causes this equality to be satisfied. IRR can be interpreted as the expected rate of income from a given project and compared with the rates of return on other, alternative methods of allocating investment expenditures, e.g., bank deposits. Investments in which the IRR is higher than the adopted level should be considered satisfactory.

\subsection{Methodology for Calculating the Costs of Reducing Greenhouse Gas Emissions}

The use of energy from renewable sources is accompanied by a systemic reduction in GHG (Green House Gases) emissions, in particular $\mathrm{CO}_{2}$ emissions. This is because renewable energy is not credited with emissions of these gases. At the same time, since renewable energy replaces non-renewable energy carriers, which are the source of GHG emissions, it is this emission of equivalent non-renewable energy that is considered to be reduced in the system. As a first approximation, it is assumed that this emission reduction costs as much as replacing conventional energy with renewable energy. The basic difficulty results from the fact that, for the comparison of various renewable energy sources, the cost of emission reduction should be expressed by a single, synthetic indicator (EUR/tonne GHG emission reduction), while the implementation of individual RES technologies may be very diverse in terms of the investment process schedule, the proportion of different cost components, etc. To achieve comparability in the economic calculus, the technique of discounting and leveling costs and benefits is used. By discounting costs and benefits achieved in future years, their value is reduced to the current level of NPV (Net Present Value) [53]. The values that appear in the future years are of less importance from the perspective of today. A measure of this decrease in value may be, for example, interest rates on bank deposits (but not only).

$$
\mathrm{NPV}=\sum_{t=0}^{T} \frac{C_{t}}{(1+i)^{t}}
$$

where: $C_{t}$-net cost (after deducting the benefits achieved) in year $t, i-$ discount rate; a fixed discount rate of $8 \%$ was adopted for further analyzes, $t$-another year of implementation of the project. 
The thus calculated discounted cost of the entire project is the basis for calculating the so-called LC (Levelised Cost). A leveled cost is a hypothetical annual cost that, incurred in an equal amount throughout all years of the project implementation, would lead (after discounting) to the same NPV as the real program for the implementation of the project (with any time distribution of costs incurred) [54-56].

$$
\mathrm{LC}=\operatorname{NPV} \sum_{t=1}^{T}(1+i)^{t}
$$

The leveled cost is a measure of the net costs averaged for the entire period (costs minus benefits) of the project implementation. This parameter was used to compare different projects in terms of annual costs. In turn, the twin similar LCER (Levelised Costs of Emission Reduction) parameter was used to determine the measure of the averaged annual GHG emission reduction costs. This parameter is expressed by the formula [54-56]:

$$
\mathrm{LCER}=\frac{\operatorname{LC} \sum_{t=1}^{T}(1+i)^{t}}{\sum_{t=1}^{T} E R_{t}(1+i)^{t}}
$$

where: LCER-leveled annual cost of GHG emission reduction, EUR/t $\mathrm{CO}_{2}$ eq/year; $\mathrm{CO}_{2}$ eq-the sum of various $\mathrm{GHG}$ emissions expressed as $\mathrm{CO}_{2}$ equivalent emissions; $E R_{t}$-reduction of $\mathrm{GHG}$ emissions in year $t, t \mathrm{CO}_{2}$ eq.

Equivalent carbon dioxide emissions $\mathrm{CO}_{2}$ eq. results from the value of the GWP (Global Warming Potential) coefficients, which define the relative relations of the effects of climate warming caused by various greenhouse gases in relation to the effects caused by $\mathrm{CO}_{2}$ emissions. For $\mathrm{CO}_{2}, \mathrm{GWP}=1$ by definition. The GWP values for the remaining gases depend on the plotted time horizon in which the effects of the presence of gases in the atmosphere are considered. In this paper, a 100-year time horizon was adopted, for which the GWP for the remaining GHG significant in the energy sector are respectively: for $\mathrm{CH}_{4}$ 31 , for $\mathrm{N}_{2} \mathrm{O}-310$. The parameter calculated with the above assumptions-horizontal, marginal cost of emission reduction-represents averaged over all years of the project implementation cost of GHG emission reduction. It can be used to compare individual renewable technologies from the point of view of the economic effectiveness of reducing GHG emissions.

\section{Results and Discussion}

\subsection{Return on Investment Analyzes}

RES implementations and technologies selected on the basis of surveys as representative and subject to economic assessment have the following technical and economic characteristics, presented in Table 1.

For comparative purposes, all RES technologies were treated only as energy technologies and no non-energy benefits or additional costs to obtain them were taken into account. This mainly concerns the technology of biogas production from slurry and biogas from sewage sludge, waste biomass combustion and small hydropower plants. In these cases, the investment may take into account the costs avoided related to alternative waste management or expenses related to the development of small water retention. These are additional factors that improve the economic profitability of an investment, but cannot be universally applied, and often visible only at a higher level of analysis (at the level of, for example, a commune rather than a single project).

Table 2 presents the basic economic parameters of the researched investments in the absence of support mechanisms, i.e., investments located at the user's site with average prices of conventional energy carriers, with no subsidies, exemptions and tax exemptions, and with a standard depreciation rate and a commercial loan taken for the construction of the installation. investment. Most of the analyzed technologies show energy production costs lower or comparable to the costs of the replaced conventional energy carriers. These are: solar collectors, small biomass boilers, small hydropower plants and installations 
using landfill gas to produce electricity, and straw-fired heating plants. The presented table shows that for most of the analyzed investments, the results of the standard microeconomic calculation have economic justification. This means that the internal rate of return on investment expenditures is positive, and the accompanying period of return on investment expenditures is shorter than 20 years (the maximum period of economic efficiency assessment included in the applied mathematical model).

Table 1. Technical and economic characteristics of the researched implementations in RES technology.

\begin{tabular}{|c|c|c|c|c|}
\hline Analyzed Technology/RES Investment & $\begin{array}{l}\text { Installed Electric } \\
\text { Power (el) or } \\
\text { Thermal (th) }\end{array}$ & $\begin{array}{c}\text { Total Investment } \\
\text { Outlays, EUR per } 1 \mathrm{~kW} \\
\text { of Installed Capacity }\end{array}$ & $\begin{array}{l}\text { Capacity in } \mathrm{kWh} \text { per } 1 \mathrm{~kW} \text { of } \\
\text { Installed Electric Power }\end{array}$ & $\begin{array}{l}\text { Efficiency in GJ per } 1 \mathrm{~kW} \text { of } \\
\text { Installed Thermal Power }\end{array}$ \\
\hline Solar collector for water heating, $\mathrm{kW}_{\mathrm{th}}$ & 2.4 & 455.66 & & 3.1 \\
\hline Low-power straw fired boiler, $\mathrm{kW}_{\text {th }}$ & 65 & 46.31 & & 3.9 \\
\hline Wood chip boiler, $\mathrm{kW}_{\text {th }}$ & 500 & 79.14 & & 6.9 \\
\hline Geothermal heating plant, $\mathrm{kW}_{\text {th }}$ & 7500 & 310.87 & & 6.1 \\
\hline Agricultural biogas plant for slurry, $\mathrm{kW}_{\text {th }}$ & 15 & 975.66 & & 27.3 \\
\hline Photovoltaic system, $\mathrm{kW}_{\mathrm{el}}$ & 3.92 & 6313.48 & 640 & \\
\hline A small hydroelectric power plant, $\mathrm{kW}_{\mathrm{el}}$ & 90 & 1840.44 & 3264 & \\
\hline $\begin{array}{l}\text { Installation for the use of landfill gas for the } \\
\text { production of electricity } \mathrm{kW}\end{array}$ & 400 & 1222.40 & 5816 & \\
\hline Grid wind farm, $\mathrm{kW}_{\mathrm{el}}$ & 1200 & 1108.48 & 945 & \\
\hline $\begin{array}{l}\text { Municipal biogas plant for sewage sludge } \\
\text { for the production of combined electricity, } \\
\mathrm{kW}_{\mathrm{el}} \text { and heat, } \mathrm{kW}_{\mathrm{th}}\end{array}$ & $\begin{array}{l}320 \\
540\end{array}$ & 663.27 & 3451 & 11.3 \\
\hline $\begin{array}{l}\text { Installation for the use of landfill gas for } \\
\text { combined electricity production, } \mathrm{kW}_{\mathrm{el}} \text { and } \\
\text { heat, } \mathrm{kW}_{\mathrm{th}}\end{array}$ & $\begin{array}{l}550 \\
700\end{array}$ & 1280.87 & 5231 & 26.4 \\
\hline
\end{tabular}

Source: own based on [53-58].

Table 2. List of economic parameters of the researched investments in the absence of support.

\begin{tabular}{|c|c|c|c|c|c|c|}
\hline $\begin{array}{l}\text { RES Technology and Installed Electric } \\
\text { Capacity (el) and Heat (th) }\end{array}$ & IRR, \% & NPV, EUR & $\begin{array}{l}\text { PBT Discounted } \\
\text { Payback Period, } \\
\text { Years }\end{array}$ & $\begin{array}{l}\text { SPBT, Simple } \\
\text { Payback Period, } \\
\text { Years }\end{array}$ & $\begin{array}{l}\text { The Cost of Heat } \\
\text { Generation, } \\
\text { EUR/GJ }\end{array}$ & $\begin{array}{l}\text { Electricity } \\
\text { Production Cost, } \\
\text { EUR/kWh }\end{array}$ \\
\hline Solar collector for water heating, $2.4 \mathrm{~kW}_{\text {th }}$ & 8.7 & 69.35 & 11.6 & 7.6 & 32.18 & \\
\hline Low-power straw fired boiler, $65 \mathrm{~kW}_{\text {th }}$ & 31.2 & $67,611.31$ & 4.8 & 3.1 & 4.57 & \\
\hline Wood chip boiler, $500 \mathrm{~kW}_{\text {th }}$ & 34.7 & 9345.87 & 5.1 & 3.9 & 5.44 & \\
\hline Geothermal heating plant, $7500 \mathrm{~kW}_{\text {th }}$ & $<0^{(a)}$ & $-4,271,233.3$ & $>20^{\text {(b) }}$ & 13.2 & & 0.12 \\
\hline Agricultural biogas plant for slurry, $15 \mathrm{~kW}_{\mathrm{th}}$ & $<0^{\text {(a) }}$ & $-25,960.22$ & $>20^{(b)}$ & 14.8 & 12.61 & \\
\hline Photovoltaic system, $3.92 \mathrm{~kW}_{\mathrm{el}}$ & 12.64 & 6166.09 & 7.87 & 8.9 & & 0.87 \\
\hline A small hydroelectric power plant, $90 \mathrm{~kW}_{\mathrm{el}}$ & 12.1 & $20,232.83$ & 11.2 & 5.2 & & 0.55 \\
\hline $\begin{array}{l}\text { Installation for the use of landfill gas for the } \\
\text { production of electricity, } 400 \mathrm{~kW}_{\mathrm{el}}\end{array}$ & 8.9 & $63,739.14$ & 10.2 & 6.4 & & 0.52 \\
\hline Grid wind farm, $2 \times 600 \mathrm{~kW}_{\mathrm{el}}$ & $<0^{(a)}$ & $-1,535,531.9$ & $>20^{(\mathrm{b})}$ & 13.5 & & 0.23 \\
\hline $\begin{array}{l}\text { Municipal biogas plant for sewage sludge for } \\
\text { the production of combined electricity, } 320 \mathrm{~kW}_{\mathrm{el}} \\
\text { and heat, } 540 \mathrm{~kW}_{\mathrm{th}}\end{array}$ & 2.9 & $-302,483.92$ & 13.1 & 10.8 & (c) & $0.31^{\text {(c) }}$ \\
\hline $\begin{array}{l}\text { Installation for the use of landfill gas for } \\
\text { combined electricity production, } \mathrm{kW}_{\mathrm{el}} 550 \mathrm{~kW}_{\mathrm{el}} \\
\text { and heat, } 700 \mathrm{~kW}_{\mathrm{th}}\end{array}$ & $-2.8^{(a)}$ & $-1,402,158.7$ & $>20^{(b)}$ & 8.6 & (c) & $0.12^{\text {(c) }}$ \\
\hline
\end{tabular}

Source: own based on [53-58]. (a) in cases where IRR $<0$ value is not provided due to lack of economic justification, ${ }^{\text {(b) }}$ the mathematical model used for economic analyzes does not allow for the calculation of the payback period directly if it is longer than 20 years, (c) in accordance with the adopted methodological assumptions for combined heat and power installations, only the cost of electricity production was calculated, with the calculation of revenues from the use of thermal energy reducing the annual operating costs of a given installation (depreciation and operation).

The combined results show a large discrepancy in the so-called Simple Payback Period (SPBT) and Discounted Payback Period (PBT). This confirms the high sensitivity of RES technologies to the discount rate and the interest rate on investment loans. SPBT is only an auxiliary and indicative indicator. In practice, the investor is interested in the results of economic assessments made in the so-called dynamic economic environment, i.e., taking into account the time value of money. The assumed $18 \%$ minimum internal rate of return, which satisfies the investor and ensures the possibility of commercial loan repayment, was obtained for three technologies. These are a solar collector and solid biofuel boilers (straw and wood), respectively. In practice, these technologies can develop on a commercial basis. The second group of renewable energy technologies is the one that allows to obtain a rate of return higher than zero but lower than the interest rate on loans and not necessarily satisfactory for the investor. The rate of return on inputs is comparable to the current rate 
of inflation. The payback period for investment expenditures calculated for this group is in fact shorter than the durability period, but usually exceeds 10 years. These investments require support in the form of a preferential loan or a better location in terms of available renewable energy resources, technical conditions for the construction of installations, more favorable prices for energy from fossil fuels obtained in a given place. A small hydropower plant and a landfill gas installation are used to produce and sell electricity to the grid and are particularly sensitive to the energy purchase price offered by utilities. Obtaining the highest purchase price offered by power plants in Poland in 2021 of 319.6 MWh would allow to obtain full economic profitability of the investment and would not require co-financing of the investment from public funds. It is worth noting here that although the highest possible price was used for the calculations, it is still approx. border. The use of the available preferential loan for pro-ecological investments clearly improves the economic parameters. It can be assumed that, with a rate of return on investment of $13 \%$, some investors could already take the risk of investing. Supporting investments through a preferential loan with a subsidy from the state budget for interest repayment will involve real expenses (taking into account the inflation rate) in the amount of $333.92 \mathrm{EUR} / \mathrm{kW}$ of installed capacity for a small hydroelectric power plant and $425.72 \mathrm{EUR} / \mathrm{kW}$ of installed capacity for a landfill gas installation. For the remaining groups of technologies, the incentives in the form of the highest possible price for energy sold or replaced and in the form of a preferential loan turned out to be too weak to achieve economic profitability. In these cases, it is necessary to use direct subsidies to investments. For further analyzes, the subsidy thresholds set by the EcoFund were proposed for the next three RES technologies listed in Table 3, i.e., 30\% of investment expenditures (the maximum subsidy available to commercial companies) and $50 \%$ of investment expenditures (subsidies available only to investors from the public sector and non-governmental organizations).

Table 3. Economic parameters of the investment with the support of the investor with a subsidy of $50 \%$ of the total investment expenditure.

\begin{tabular}{|c|c|c|c|c|}
\hline RES Technologies & IRR, \% & NPV, EUR & PBT, Years & $\begin{array}{c}\text { The Amount of Subsidies, } \\
\text { EUR/kW }\end{array}$ \\
\hline Solar collector for water heating, $2.4 \mathrm{~kW}_{\text {th }}$ & 22.6 & 1298.27 & 7.2 & 224.57 \\
\hline $\begin{array}{l}\text { Municipal biogas plant for sewage sludge for the } \\
\text { production of combined electricity, } 320 \mathrm{~kW}_{\mathrm{el}} \text { and } \\
\text { heat, } 540 \mathrm{~kW}_{\mathrm{th}}\end{array}$ & 22.8 & $380,597.18$ & 6.7 & 464.35 \\
\hline $\begin{array}{l}\text { Installation for the use of landfill gas for } \\
\text { combined electricity production, } 550 \mathrm{~kW}_{\mathrm{el}} \text { and } \\
\text { heat, } 700 \mathrm{~kW}_{\text {th }}\end{array}$ & 15.7 & $526,954.35$ & 7.9 & 640.44 \\
\hline
\end{tabular}

Source: own study [53-58].

Other technologies where IRR $<0$ requires stronger support mechanisms, and in particular higher investment subsidies than those available on general terms. Forecasting the technology development support scenario at the subsidy level of $70 \%$, they show a positive NPV value and a rate of return that enables the implementation of the investment. In this group, the RES technology that has a chance, under certain conditions, for a relatively easy improvement of economic parameters, is the biogas production technology. In the analyzed case, an agricultural biogas plant is used to produce only biogas used for heating purposes. A clear improvement in economic parameters could be achieved by using the fermented slurry for the production of compost or by introducing a diesel generator into the system. The analysis carried out shows that for farms dealing with breeding and plant production there are reasons to obtain an appropriate amount of waste for the production of biogas and, consequently, for the generation of electricity and heat. The production of biogas can be based on waste material of agricultural origin, both animal and vegetable. The use of the substrate in the form of a mixture of slurry and maize silage provides a significant amount of biogas, the possibility of slurry disposal and the production of a significant amount of "green electricity and heat" in cogeneration systems. On a farm, 
the use of maize silage for biogas production will result in the fact that the co-fermentation has a high energy potential and stable quality, which makes it possible to plan stocks for supplying biogas plants. Moreover, the use of biofuels has a positive effect on the environment, as it limits the use of natural resources of fossil fuels and contributes to the reduction of the greenhouse effect. In addition, the production of agricultural biogas allows the use of agricultural and food industry waste as well as manure and plant waste produced by farms for the production of both ecological fuel and natural fertilizers. In this way, the risk of biogas escaping into the atmosphere can be prevented, which contributes to the reduction of the greenhouse effect and the formation of uncontrolled fires caused by the burning of waste by farmers.

In addition to subsidies for investments, other, less radical support mechanisms were examined, including reduction of the VAT rate for equipment in RES technology, income tax exemption for a period of 5 years, accelerated depreciation and their combination with a preferential loan, a moderate surcharge for the sold) energy and investment subsidies. Two additionally considered support mechanisms: income tax exemption and accelerated depreciation for RES technologies producing energy for sale (to the grid), have only a slight impact on the improvement of economic parameters. The income tax exemption as the only support tool had only a minor impact on the improvement of economic parameters of two technologies: small hydropower plant (IRR increased from 11.2 to 11.7) and landfill gas installations for electricity production (IRR increased from 9.4 to 9.9). Accelerated depreciation brought only a minimal increase in IRR for a small hydropower plant (from 11.2 to 11.3), and in several other cases it even had a negative impact on the results of economic assessments. Both of the above-mentioned support tools are important for technologies that are already profitable, if we additionally want to increase their attractiveness. An interesting concept of financial support for investments in RES technologies is a combination of a preferential loan (in the case under consideration with an interest rate of $8 \%$ ) and the level of subsidy required to obtain the expected internal rate of return (in the case under consideration-18\%). The assessment of the impact of the simultaneous application of a preferential loan and a subsidy on the amount of the necessary subsidy and the amount of subsidies to investments from public funds is presented in Table 4.

Table 4. Combination of investment support conditions.

\begin{tabular}{|c|c|c|c|c|}
\hline RES Technologies & $\begin{array}{l}\text { IRR without } \\
\text { Support, \% }\end{array}$ & $\begin{array}{c}\text { IRR with a } \\
\text { Preferential Loan } \\
8 \%, \%\end{array}$ & $\begin{array}{l}\text { The Amount of the } \\
\text { Necessary Subsidy for } \\
\text { Investments with a } \\
\text { Preferential Loan, at } \\
\text { which IRR = 18\% of } \\
\text { Investment Expenditure }\end{array}$ & $\begin{array}{l}\text { The Amount of } \\
\text { Subsidies to Investments } \\
\text { from Public Funds } \\
\text { EUR/kW of } \\
\text { Installed Power }\end{array}$ \\
\hline $\begin{array}{l}\text { Solar collector for water heating } \\
2.4 \mathrm{~kW}_{\text {th }}\end{array}$ & 9.2 & 9.8 & 37.6 & 130.87 \\
\hline $\begin{array}{l}\text { Municipal biogas plant for sewage } \\
\text { sludge for the production of } \\
\text { combined electricity, } 320 \mathrm{~kW}_{\mathrm{el}} \text { and } \\
\text { heat, } 540 \mathrm{~kW}_{\text {th }} \\
\text { Installation for the use of landfill }\end{array}$ & 3.2 & 5.9 & 38.7 & 265.44 \\
\hline $\begin{array}{l}\text { Installation for the use of landfill } \\
\text { gas for combined electricity } \\
\text { production, } 550 \mathrm{~kW}_{\mathrm{el}}\end{array}$ & 9.8 & 13.1 & 21.6 & 584.79 \\
\hline $\begin{array}{l}\text { A small hydroelectric power plant, } \\
\qquad 90 \mathrm{~kW}_{\mathrm{el}}\end{array}$ & 12.1 & 12.9 & 22.1 & 472.18 \\
\hline
\end{tabular}

Source: own based on [53-58].

The combination of support conditions used in Table 5 significantly improved the economic efficiency of the investment. Above $50 \%$ of the subsidy threshold, mainly badly located technologies (water and wind), an agricultural biogas plant (without taking into account the costs related to alternative disposal of slurry) and a pilot geothermal heating plant remained. These technologies would be fully economically viable if the capital expenditure were reduced by the same percentage. Reducing investment by $20-45 \%$ for technologies entering the market does not seem particularly difficult when the starting point is demonstration projects with targeted efforts to systematically create a market. 
Therefore, the use of subsidies should be treated not as a subsidy for individual investments, but as a systemic measure aimed at the development of technologies and the market in the shortest possible time, so that the reasons for their further application disappear as soon as possible.

Table 5. Lists of the calculation results of GHG emission reduction costs by implementing RES technologies. The calculations were made for the discount rate $i=8 \%$.

\begin{tabular}{|c|c|c|c|}
\hline Technology Implemented Using RES & $\begin{array}{c}\text { The leveled Annual Cost of } \\
\text { GHG Emission } \\
\text { Reduction, EUR }\end{array}$ & $\begin{array}{l}\text { Reduction of } \mathrm{CO}_{2} \text { Emissions } \\
\text { Equivalent (GWP } 100 \text { Years), } \\
\text { tons } \mathrm{CO}_{2} / \text { year }\end{array}$ & $\begin{array}{l}\text { Leveled Unit Cost of GHG } \\
\text { Emission Reduction, EUR }\end{array}$ \\
\hline Solar collector for water heating $-4 \mathrm{~m}^{2}$ & -93.71 & 12.19 & -10.87 \\
\hline Low-power straw fired boiler- $65 \mathrm{~kW}$ & 768.05 & 48.56 & 16.74 \\
\hline Wood chip boiler- $80 \mathrm{~kW}$ & 967.83 & 102.34 & 10.1 \\
\hline Geothermal heating plant-7.3 MW & 146.96 & 6476 & 23.05 \\
\hline Agricultural biogas plant for slurry $-100 \mathrm{~m}^{3}$ & 951.53 & 69.92 & 14.35 \\
\hline Photovoltaic system-120 W & 73.27 & 0.89 & 768.92 \\
\hline A small hydroelectric power plant $-45 \mathrm{~kW}$ & -4503.27 & 296.54 & -18.92 \\
\hline $\begin{array}{l}\text { Installation for the use of landfill gas for the } \\
\text { production of electricity- }-400 \mathrm{~kW}\end{array}$ & -35.87 & 12856 & -3.14 \\
\hline $\begin{array}{l}\text { Grid wind farm-160 kW } \\
\text { Municipal biogas plant for sewage sludge for }\end{array}$ & $10,020.01$ & 165.99 & 54.35 \\
\hline $\begin{array}{l}\text { the production of combined } \\
\text { electricity-320 } \mathrm{kW}_{\mathrm{el}} \text { and heat }-540 \mathrm{~kW}_{\mathrm{th}} \\
\text { Installation for the use of landfill gas for }\end{array}$ & 2310.44 & 3876.21 & -0.66 \\
\hline $\begin{array}{l}\text { combined electricity production }-550 \mathrm{~kW} \text { el } \\
\text { and heat }-700 \mathrm{~kW}_{\text {th }}\end{array}$ & 2330.10 & 20624 & 0.22 \\
\hline
\end{tabular}

Source: own based on [53-58].

3.2. Costs of Reducing Greenhouse Gas Emissions with the Use of Renewable Energy Technologies in Poland

Table 5 presents the results of calculations of the leveled costs of emission reduction and additional parameters: the leveled annual cost of GHG emission reduction expressed in EUR of operation of the researched installation using RES, reduction of $\mathrm{CO}_{2}$ equivalent emissions due to the use of a given RES technology expressed in tonnes of $\mathrm{CO}_{2}$ eq/year, using the coefficient the conversion GWP corresponding to the 100-year period of GHG presence in the atmosphere.

Some of the renewable energy technologies are characterized by a negative horizontal cost of GHG emission reduction (solar collectors, small hydropower plant and technologies for the use of landfill gas and biogas from slurry), others have positive emission reduction costs. Negative costs mean that reducing emissions practically does not require any additional costs, on the contrary, it brings profits in the long term. Table 6 calculates the level of GHG emission reduction costs for renewable energy technologies in Poland. Then the data was compared with the results reported in the literature as model calculations of emission reduction costs for decentralized RES technologies producing electricity.

Table 6. Leveled emission reduction costs for RES technologies calculated as reference.

\begin{tabular}{ccc}
\hline $\begin{array}{c}\text { RES Technology as a } \\
\text { Reduction Option }\end{array}$ & $\begin{array}{c}\text { Technology Being Replaced, } \\
\text { Conventional }\end{array}$ & $\begin{array}{c}\text { Level Unit Cost of Emission } \\
\text { Abatement GHG, } \\
\text { USD/tonę ekw. CO } \mathbf{~}_{\mathbf{2}}\end{array}$ \\
\hline Biogas from sewage sludge & & -2321.9 \\
Landfill gas & Electricity from a coal-fired & 35.78 \\
Biogas from agricultural waste & power plant & 52.74 \\
Water power plant & & 87.22 \\
Photovoltaic system & & $31,987.85$ \\
\hline Source: own based on [53-58]
\end{tabular}

The comparison of Tables 5 and 6 shows how strong is the influence of local conditions, the specificity of a given country and the state of energy infrastructure on the system of GHG emission reduction costs. For Poland, it seems more important to compare the calculated costs of emission reductions with the purchase prices of reductions offered by Western countries. 
World Bank experts involved in the preparation of the Prototype Coal Investment Fund (CIF) estimate that at present the market accepts projects allowing to reduce GHG emissions at a cost lower than USD 50-58 per tonne equivalent. $\mathrm{CO}_{2}$. The above data indicate that almost all analyzed RES technologies can be an attractive option for reducing harmful compounds to the atmosphere. Some of them (solar energy, small hydropower and energy use of biomass) are in this context technologies exceptionally attractive economically. Some formal difficulty, especially for solar energy, may be only the small scale of the installation in relation to the administrative costs of managing the supporting mechanisms. Therefore, in the future, in the implementation of projects, the possibility of aggregating individual projects based on low-power renewable energy technologies into larger investment packages should be considered in order to reduce the unit costs of project service and at the same time achieve a greater reduction effect.

\subsection{Identifying the Ecological Benefits of Using Renewable Energy Sources in the Context of Reducing Greenhouse Gas Emissions}

The use of energy from renewable sources, in addition to the market-measurable costs and benefits associated with the implementation of these projects, there are also the so-called external costs and benefits that are not priced in the market. Examples include [59-62]:

1. on the side of potential external benefits:

- favorable impact on local labor markets by creating additional jobs in the production and operation of small renewable energy equipment,

- favorable, synergistic links between the development of renewable energy sources (especially biofuels) and the introduction of structural changes in agriculture, necessary both from the point of view of improving the economic efficiency of agricultural production in Poland as well as due to the requirements of the process of Poland's connection with the European Union,

- reduction of emissions of local air pollutants $\left(\mathrm{SO}_{2}, \mathrm{NOx}\right.$, dust, heavy metals) and thus reduction of economic losses (which are currently only partially compensated by emission charges) caused by: degradation of forest, agricultural and water ecosystems, accelerated corrosion of building elements, machinery and equipment, adverse effects of pollution on human health, etc.,

- increasing political prestige (both at the level of local communities and the entire country) in connection with the concern for the natural environment and sustainable economic development, and the creation of opportunities to reduce the civilization gap between rural and peripheral areas and urbanized regions, as well as the growth of entrepreneurship by introducing a country of new technologies,

- $\quad$ easier fulfillment of the country's international obligations concerning the reduction of local pollutants and greenhouse gas emissions (mainly $\mathrm{CO}_{2}$ ), thus reducing the costs of actions that must be taken to achieve the emission limits required by the relevant conventions on a national scale.

2. on the side of potential external costs:

- land take (this only applies to those cases where alternative, economically attractive land-use methods exist),

- $\quad$ problems in the labor markets of traditional energy carriers (e.g., in the coal sector), which may accompany the decline in demand for these carriers due to the large-scale development of renewable energy.

An individual entrepreneur does not take the above factors into account when making economic decisions. However, these elements should be taken into account by local governments and central state administration, as the enterprise is not currently experiencing their impact on the cost side or the benefit side. External costs and benefits can be internalized, i.e., introduced into the market system through appropriate legislative initiatives and 
executive decisions, both at the level of central state administration and local government authorities [63-66]: Examples of already existing methods of internalization are: the applicable fees for economic use of the environment, burdening mainly conventional energy technologies; obligation to purchase electricity and heat from renewable sources by energy network operators at a higher price; redistribution of fees for using the environment to co-finance environmental investments, etc.

\subsection{Future Gap and Implementation}

The conversion of the Polish economy to renewable energy is not only the domain of the most developed countries. Furthermore, poorer, but rapidly developing countries, which in the development of renewable energy technologies see not only the possibility of improving the well-being of their citizens, but also real economic and business opportunities, are leaning towards it. The best example is China-in recent years it has been responsible for over $40 \%$ of the global increase in electricity production from RES. Among the key factors that determine the rapid growth of the importance of renewable energy sources are, among others technological progress that reduces their costs and increases efficiency. Other important factors include the growing problem of climate change related to the excessive increase in emissions of harmful gases, regulations protecting the climate and system support for renewable energy. The green revolution is also supported by an increase in the environmental awareness of societies, reflected in the activities of consumers, and an increasingly higher one marginal cost of energy production from conventional sources, resulting, inter alia, from the deteriorating access to certain raw materials, the high degree of consumption of current generation assets and rising climate charges. The global energy sector is expected to undergo the most profound transformation in its history in the coming decades. According to the forecasts of the World Renewable Energy Organization (IRENA), virtually each of the energy transformation scenarios assumes further dynamic development of the renewable energy sector in the world. Forecasts indicate that in the coming years, depending on the adopted scenario, from 2.5 to even 4 trillion USD per year will be allocated to the energy transformation in global terms.

The countries of Central and Eastern Europe are also making progress in the area of energy transformation more and more. However, their pace is still not optimal-especially taking into account the specific features of local economies, which are characterized by relatively high levels energy consumption and $\mathrm{CO}_{2}$ emission. In 2010-2019, the production of electricity from RES in 11 Central European EU Member States grew at a slower pace than in Western Europe ( $4 \%$ compared to $6 \%$ on average annually). As a consequence, the increase in the share of renewable energy sources in final electricity consumption was also much weaker ( +8 as compared to +17 percentage points) $[3,9,12]$. The main drivers of the industry's growth in recent years were-just like in the world-wind and solar energy. Biomass and biogas also play a relatively large role in the development of the RES sector in some countries (e.g., the Czech Republic, Slovakia). Hydropower, which provides $\frac{3}{4}$ of power, is dominant in the global structure of renewable energy sources. Wind energy is in second place, producing another $9 \%$ of global energy. China has the largest share in global renewable energy production. From year to year, they are becoming a stronger and stronger leader when it comes to investing in renewable energy. They have the largest wind farm market in the world. In this way, China together with the USA, Germany and India produce global wind energy. China has also gained a dominant position in generating electricity from solar energy. Countries of the world, mainly highly developed countries, but also developing countries, are investing more and more amounts in renewable energy. The main goal of the investment is primarily to reduce the emission of harmful substances released into the environment as a result of traditional methods of obtaining energy. In addition, financial and political aspects are also important factors, i.e., independence from suppliers of fuel raw materials. When analyzing the share of renewable energy sources in total energy production in individual countries of the world, Norway ranks first with $65.5 \%$. Sweden comes in second, with the share of green power in total energy production 
being $52 \%$. In this ranking, Poland is only on the 21 st place, with nearly $12 \%$ share of green power.

The transformation of the national economy towards RES will also require meeting numerous challenges, which will result in the need to create permanent and transparent support mechanisms and to undertake a historic investment effort. One of the most important issues will be to guarantee the security of energy supply. It will require significant investments in transmission and distribution infrastructure, as well as ensuring the availability of conventional energy sources in periods of reduced activity of renewable energy installations. The energy transformation is associated with enormous expenditure, estimated in the next 20 years at least 1.6 trillion PLN. Combined with numerous and costly support mechanisms, this means the prospect of an inevitable further increase in electricity prices, and the reconstruction of the country's energy model will also require ensuring a socially fair transformation, the so-called coal regions.

\section{Conclusions}

The European Union has adopted as a long-term goal to increase energy efficiency and increase the share of renewable energy sources. Sustainable energy plays an important role in this. The comparison of the long-term potential of renewable energy and domestic coal mining confirms that both economic and technological trends will profoundly change the structure of available domestic energy sources on the Polish market. Even under the most optimistic assumptions, Polish mines will not be able to meet the growing demand of the energy sector. Even in an optimistic scenario-the support for the development of coal mining will cover less than $60 \%$ of the energy sector's demand in 2050 . In the middle of the century, domestic hard coal will satisfy only $20 \%$ of the energy sector's demand. On the other hand, the share of renewable energy sources may reach three quarters by 2050, without significant breakthroughs - the combination of different technologies is of key importance. The significant role of variable sources (wind and sun) means that achieving a high share of RES requires flexibility at the system level. Maintaining significant energy independence requires a shift towards a new paradigm: large-scale investments in low-carbon technologies, the gradual transfer of coal-fired power plants to the reserve, development of cross-border connections and the search for efficient energy storage options.

When making a decision on investing in renewable energy sources, it should be remembered that only a complete and correctly conducted analysis of the profitability of a renewable energy investment, which was presented in a given paper, allows you to make an informed and correct decision regarding the taking or abandonment of the planned project. The results of such an analysis are strictly dependent on the values of individual parameters, which should be selected very carefully and thoughtfully. This particularly applies to assumptions about the cost of equity capital (including the assumed level of investment risk) and the time value of money (inflation rate, income reinvestment rate, etc.). In order to assess the profitability of an investment, it is recommended to conduct a discounted analysis and to use dynamic indicators, i.e., taking into account the time factor. In the case of atypical nature of cash flows, it is recommended to use the ratios in a modified version, i.e., taking into account a separate income reinvestment rate. When comparing various investment projects, you should be consistent in selecting individual financial and technical parameters and compare investments with the same implementation periods. Using renewable energy sources is certainly profitable, but one must to take into account quite a large one-time expenditure when buying and installing equipment. Such an investment usually returns after a minimum of several years-depending on the solution we decide on. The conducted analyzes also show several important conclusions:

1. The economic analysis of the use of RES technologies carried out in the study allows for their division into groups:

- technologies that achieve an internal rate of return equal to or higher than the interest rate of commercial loans, i.e., solar collectors and wood and straw boilers. 
- technologies for which the rate of return on investment is lower than the commercial loan interest rate, but above zero. This group includes small hydropower plants built on existing weirs, installations using gas landfill for electricity production, solar collectors for heating water and municipal biogas plants that produce electricity and heat in combination. The first three technologies in this group have an internal rate of return higher on the interest rate on preferential loans $(8 \%)$. Sewage sludge biogas plants (built on the basis of foreign technology) and solar collectors for heating utility water require subsidies of up to $30 \%$ of investment outlays.

- technologies under analysis that aim to achieve an internal rate of return above the current interest rate for investment loans (18\%) require support in the form of subsidies amounting to $70 \%$ of investment outlays. These are: automatic straw and wood chip heating plants, wind farms network and small hydropower plants built from scratch with dams. In this group of technologies, economic parameters can be improved by extending the lifetime of biomass heating plants and the location of the power plant wind turbines in locations with higher wind speeds. technologies that can be implemented as funded demonstration projects from outside. This group includes agricultural biogas plants, geothermal and small heating plants grid wind farms, photovoltaic systems. Improving parameters economic benefits of some technologies in this group can be obtained under the conditions combining energy production with other types of production, e.g., for biogas plants agriculture, a significant improvement in economic indicators would be achieved through production compost from fermented slurry, providing for geothermal heating plants heat reception for a longer period of the year.

2. The economic assessment of renewable energy technologies can also be made in terms of the pace of return investment outlays. The results are presented in Tables 2-4.

3. Indirect support mechanisms in the form of tax breaks and accelerated depreciation on their own, they turn out to be insufficient for most RES technologies under conditions national and it is necessary to apply direct financial incentives in the form of subsidies.

Funding: This research received no external funding.

Institutional Review Board Statement: Not applicable.

Informed Consent Statement: Not applicable.

Data Availability Statement: Not applicable.

Conflicts of Interest: The author declares no conflict of interest.

\section{References}

1. Shahzad, U.; Radulescu, M.; Rahim, S.; Isik, C.; Yousaf, Z.; Ionescu, S. Do Environment-Related Policy Instruments and Technologies Facilitate Renewable Energy Generation? Exploring the Contextual Evidence from Developed Economies. Energies 2021, 14, 690. [CrossRef]

2. Directive 2009/28/EC of the European Parliament and of the Council of 23 April 2009 on the Promotion of the Use of Energy from Renewable Sources and Amending and Subsequently Repealing Directives 2001/77/EC and 2003/30/EC (Text with EEA Relevance). Available online: https://eur-lex.europa.eu/legal-content/PL/TXT/?uri=celex\%3A32009L0028 (accessed on 15 October 2021).

3. Eurostat. Statistics Explained, Electricity Price Statistics. Available online: https://ec.europa.eu/eurostat/statistics-explained/ index.php/Electricity_price_statistics (accessed on 13 October 2021).

4. Janoś, K. Polski Prąd Najdroższy w UE już 7 m-c z Rzędu. Tak Drogo Może Być 15 lat. Available online: https:/ / www.money. pl/gospodarka/polski-prad-najdrozszy-w-ue-juz-7-miesiecy-z-rzedu-tak-drogo-moze-byc-15-lat-6576934583294752a.html (accessed on 13 October 2021).

5. Olczak, P.; Matuszewska, D.; Kryzia, D. "Mój Prąd” as an Example of the Photovoltaic One off Grant Program in Poland. Energy Policy J. 2020, 23, 123-138. Available online: https: / epj.min-pan.krakow.pl/-Moj-Prad-as-an-example-of-the-photovoltaic-oneoff-grant-program-in-Poland,122482,0,2.html (accessed on 13 October 2021). [CrossRef] 
6. Benalcazar, P.; Suski, A.; Kamiński, J. The Effects of Capital and Energy Subsidies on the Optimal Design of Microgrid Systems. Energies 2020, 13, 955. [CrossRef]

7. Newseria BIZNES. Polska na Piątym Miejscu w UE pod Względem Rozwoju Fotowoltaiki. Ten Rok Może być Rekordowy dla Branży. Available online: http://europejskafirma.pl/24168,polska-na-piatym-miejscu-w-ue-pod-wzgledem-rozwojufotowoltaiki-ten-rok-moze-byc-rekordowy-dla-branzy/ (accessed on 17 October 2021).

8. SolarPower Europe. Leading the Energy Transition. Available online: https://www.solarpowereurope.org/events2/solarpowersummit-2/ (accessed on 14 October 2021).

9. Instytut Energetyki Odnawialnej (IEO). Główny Raport Solar “Rynek Fotowoltaiki w Polsce 2019”. Available online: https: / /ieo.pl/pl/projekty/raport-rynek-fotowoltaiki-w-polsce-2019 (accessed on 17 October 2021).

10. International Energy Agency (IEA). World Energy Outlook 2019-Analysis_IEA; IEA Publications: Paris, France, 2019; ISBN 978-92-64-97300-8.

11. The Sejm of the Republic of Poland. Act of 19 July 2019 Amending the Renewable Energy Sources Act and Certain Other Acts (Dz.U. 2019 Proz. 1524). Available online: http:/ / isap.sejm.gov.pl/isap.nsf/download.xsp/WDU20190001524/T/D20191524L. pdf (accessed on 14 October 2021).

12. Organisation for Economic Cooperation and Development (OECD). Better Policies for Better Lives. Available online: https://www.oecd-ilibrary.org/social-issues-migration-health/international-migration-outlook-2020_ec98f531-en (accessed on 13 October 2021).

13. Ministry of State Assets. Polityka Energetyczna Polski do 2040 r.-Strategia Rozwoju Sektora Paliwowo-Energetycznego, Warsaw, Poland, 2019. Available online: https://www.gov.pl/web/aktywa-panstwowe/zaktualizowany-projekt-polityki-energetycznejpolski-do-2040-r (accessed on 13 October 2021).

14. Kapłan, R.; Kopacz, M. Economic Conditions for Developing Hydrogen Production Based on Coal Gasification with Carbon Capture and Storage in Poland. Energ. Electron. J. 2020, 13, 5074. [CrossRef]

15. Ministry of Culture and Environment. Polityka Energetyczna Polski do 2030 roku. Available online: https://www.gov.pl/web/ klimat/polityka-energetyczna-polski-do-2030-roku (accessed on 12 October 2020).

16. Paris Agreement. 2015. Available online: https://unfccc.int/process-and-meetings/the-paris-agreement/the-paris-agreement (accessed on 6 October 2021).

17. Dogan, E.; Ulucak, R.; Kocak, E.; Isik, C. The Use of Ecological Footprint in Estimating the Environmental Kuznets Curve Hypothesis for BRICST by Considering Cross-Section Dependence and Heterogeneity. Sci. Total Environ. 2020, $723,138063$. [CrossRef] [PubMed]

18. Alvarado, R.; Tillaguango, B.; Dabar, V.; Ahmad, M.; Isik, C. Ecological footprint, economic complexity and natural resources rents in Latin America: Empirical evidence using quantile regressions. J. Clean. Prod. 2021, 318, 128585. [CrossRef]

19. Isik, C.; Ahmad, M.; Ongan, S.; Ozdemir, D.; Ifran, M.; Alvarado, R. Convergence Analysis of the Ecological Footprint: Theory and Empirical Evidence from the USMCA Countries. Environ. Sci. Pollut. Res. 2021, 28, 32648-32659. [CrossRef]

20. Derski, B. Energetyka w Polsce w 2019 Roku-Moc i Produkcja Energii wg Danych PSE. Available online: https: / / wysokienapiecie. pl/27524-energetyka-w-polsce-w-2019-roku-moc-produkcja-energii-wg-danych-pse/ (accessed on 13 October 2021).

21. Ahmad, M.; Isik, C.; Jabeen, G.; Ali, T.; Ozturk, I.; Atchike, D. Heterogeneous links among urban concentration, non-renewable energy use intensity, economic development, and environmental emissions across regional development levels. Sci. Total Environ. 2021, 765, 144527. [CrossRef] [PubMed]

22. Isik, C.; Radulescu, M. Investigation of the relationship between renewable energy, tourism receipts and economic growth in Europe. Stat.-Stat. Econ. J. 2017, 97, 85-94.

23. European Green Deal 2019. Available online: https:/ / www.consilium.europa.eu/en/policies/green-deal/ (accessed on 10 October 2021).

24. Neutralna Emisyjnie Polska 2050; Raport; McKinsey \& Company: Warszawa, Poland, 2020.

25. Wróblewski, P.; Lewicki, W. A Method of Analyzing the Residual Values of Low-Emission Vehicles Based on a Selected Expert Method Taking into Account Stochastic Operational Parameters. Energies 2021, 14, 6859. [CrossRef]

26. Wróblewski, P. Analysis of Torque Waveforms in Two-Cylinder Engines for Ultralight Aircraft Propulsion Operating on 0W-8 and 0W-16 Oils at High Thermal Loads Using the Diamond- Like Carbon Composite Coating. SAE Int. J. Engines 2022, 15, 2022. [CrossRef]

27. Wróblewski, P.; Koszalka, G. An Experimental Study on Frictional Losses of Coated Piston Rings with Symmetric and Asymmetric Geometry. SAE Int. J. Engines 2021, 14, 1946-3944. [CrossRef]

28. Wróblewski, P. An Innovative Approach to Data Analysis in The Field of Energy Consumption and Energy Conversion Efficiency in Vehicle Drive Systems-The Impact of Operational and Utility Factors. In Proceedings of the 37th International Business Information Management Association (IBIMA), Cordoba, Spain, 30-31 May 2021.

29. Lewicki, W.; Wróblewski, P. The Impact of the COVID-19 Pandemic on The Development of Electromobility-Analysis of Changes in Purchasing Preferences. In Proceedings of the 37th International Business Information Management Association (IBIMA), Cordoba, Spain, 30-31 May 2021.

30. Wróblewski, P.; Drożdż, W.; Lewicki, W.; Miązek, P. Methodology for Assessing the Impact of Aperiodic Phenomena on the Energy Balance of Propulsion Engines in Vehicle Electromobility Systems for Given Areas. Energies 2021, 14, 2314. [CrossRef]

31. Wróblewski, P.; Drożdż, W.; Lewicki, W.; Dowejko, J. Total Cost of Ownership and Its Potential Consequences for the Development of the Hydrogen Fuel Cell Powered Vehicle Market in Poland. Energies 2021, 14, 2131. [CrossRef] 
32. Wróblewski, P.; Kupiec, J.; Drożdż, W.; Lewicki, W.; Jaworski, J. The Economic Aspect of Using Different Plug-in Hybrid Driving Techniques in Urban Conditions. Energies 2021, 14, 3543. [CrossRef]

33. Wróblewski, P. Technology for Obtaining Asymmetries of Stereometric Shapes of the Sealing Rings Sliding Surfaces for Selected Anti-Wear Coatings. In Proceedings of the SAE Powertrains, Fuels \& Lubricants Meeting, Kraków, Poland, 22-24 September 2020; SAE International: Warrendale, PA, USA, 2020. [CrossRef]

34. Wróblewski, P.; Iskra, A. Problems of Reducing Friction Losses of a Piston-Ring-Cylinder Configuration in a Combustion Piston Engine with an Increased Isochoric Pressure Gain. In Proceedings of the SAE Powertrains, Fuels \& Lubricants Meeting, Kraków, Poland, 22-24 September 2020; SAE International: Warrendale, PA, USA, 2020. [CrossRef]

35. Lewicki, W.; Drozdz, W.; Wroblewski, P.; Zarna, K. The Road to Electromobility in Poland: Consumer Attitude Assessment. Eur. Res. Stud. J. 2021, 24, 28-39. [CrossRef]

36. Wróblewski, P.; Iskra, A. Geometry of shape of profiles of the sliding surface of ring seals in the aspect of friction losses and oil film parameters. Combust. Engines 2016, 167, 24-38. [CrossRef]

37. Snoek, M. The Use and Methodology of Scenario Making. Eur. J. Teach. Educ. 2003, 26, 9-19. [CrossRef]

38. Kraan, O.; Chappin, E.; Kramer, G.J.; Nikolic, I. The influence of the energy transition on the significance of key energy metrics. Renew. Sustain. Energy Rev. 2019, 111, 215-223. [CrossRef]

39. Edmonts, J.; Wilson, T.; Wise, M.; Weyant, M. Electrification of the economy and CO2 emissions mitigation. Environ. Econ. Policy Stud. 2006, 7, 175-203. [CrossRef]

40. Gabriel, J. A scientific enquiry into the future. Eur. J. Future Res. 2014, 2, 31. [CrossRef]

41. Dahl, C.A. Book Review-International Energy Markets: Understanding Pricing, Policies, and Profits. Energy J. 2006, $27,179-181$. [CrossRef]

42. Hölsgens, R.; Lübke, S.; Hasselkuß, M. Social innovations in the German energy transition: An attempt to use the heuristics of the multi-level perspective of transitions to analyze the diffusion process of social innovations. Energy Sustain. Soc. 2018, 8,8 . [CrossRef]

43. Zimm, C.; Goldemberg, J.; Nakicenovic, N.; Busch, S. Is the renewables transformation a piece of cake or a pie in the sky? Energy Strat. Rev. 2019, 26, 100401. [CrossRef]

44. Zundel, S. Time Strategies, Innovation and Environmental Policy; Edward Elgar Publishing: Cheltenham, UK, 2005.

45. Gielen, D.; Boshell, F.; Saygin, D.; Bazilian, M.D.; Wagner, N.; Gorini, R. The role of renewable energy in the global energy transformation. Energy Strategy Rev. 2019, 24, 38-50. [CrossRef]

46. Höfer, T.; Madlener, R. A participatory stakeholder process for evaluating sustainable energy transition scenarios. Energy Policy 2020, 139, 111277. [CrossRef]

47. Rouzbahani, H.M.; Karimipour, H.; Lei, L. A review on virtual power plant for energy management. Sustain. Energy Technol. Assess. 2021, 47, 101370. [CrossRef]

48. Bhuiyan, E.A.; Hossain, Z.; Muyeen, S.; Fahim, S.R.; Sarker, S.K.; Das, S.K. Towards next generation virtual power plant: Technology review and frameworks. Renew. Sustain. Energy Rev. 2021, 150, 111358. [CrossRef]

49. Teufel, B.; Sentic, A.; Barmet, M. Blockchain energy: Blockchain in future energy systems. J. Electron. Sci. Technol. 2019, 17, 100011. [CrossRef]

50. Lei, N.; Masanet, E.; Koomey, J. Best practices for analyzing the direct energy use of blockchain technology systems: Review and policy recommendations. Energy Policy 2021, 156, 112422. [CrossRef]

51. Borowski, P. Adaptation strategy on regulated markets of power companies in Poland. Energy Environ. 2019, 30, 3-26. [CrossRef]

52. Kochanek, E. Wielowymiarowość Interesów Energetycznych w Dobie Transformacji Systemowej; WAT: Warsaw, Poland, 2021.

53. Polityka Energetyczna Polski 2040, Załącnik do Uchwały nr 22/2021 Rady Ministrów z Dnia 2 Lutego 2021 r; Ministerstwo Klimatu i Środowiska: Warsaw, Poland, 2021.

54. Niekurzak, M.; Kubińska-Jabcoń, E. Analysis of the Return on Investment in Solar Collectors on the Example of a Household: The Case of Poland. Front. Energy Res. 2021, 9, 1-12. [CrossRef]

55. Wiśniewski, G. Europejskie Centrum Energii Odnawialnej, Ekonomiczne i Prawne Aspekty Wykorzystania Odnawialnych Źródeł Energii w Polsce; Warsaw, Poland, 2000. Available online: http://www.pga.org.pl/prawo/ekonomiczne_i_prawne_aspekty.pdf (accessed on 13 October 2021).

56. Szczerbowski, R. The forecast of Polish power production sector development by 2050—Coal scenario. Energy Policy J. 2018, 19, 5-18.

57. Młynarski, T.; Tarnawski, M. Źródła Energii i ich Znaczenie dla Bezpieczeństwa Energetycznego w XXI Wieku; Difin: Warsaw, Poland, 2016.

58. Wnioski z Analiz Prognostycznych na Potrzeby Polityki Energetycznej Polski do 2050 Roku, Załacznik 2; Ministerstwo Klimatu i Środowiska: Warsaw, Poland, 2021.

59. Księżopolski, K.; Maśloch, G. Time Delay Approach to Renewable Energy in the Visegrad Group. Energies 2021, 14, 1928. [CrossRef]

60. Gabryś, H. Elektroenergetyka w Polsce 2020. Energetyka 2020, 8, 365-373.

61. Robaina, M.; Neves, A. Complete decomposition analysis of $\mathrm{CO}_{2}$ emissions intensity in the transport sector in Europe. Res. Transp. Econ. 2021, 87, 101074. [CrossRef]

62. Polski Sektor Energetyczny 2050. 4 Scenariusze; Forum Energii: Warsaw, Poland, 2018. 
63. Gürsan, C.; de Gooyert, V. The systemic impact of a transition fuel: Does natural gas help or hinder the energy transition? Renew. Sustain. Energy Rev. 2021, 138, 110552. [CrossRef]

64. Gawlik, L.; Mokrzycki, E. Changes in the Structure of Electricity Generation in Poland in View of the EU Climate Package. Energies 2019, 12, 3323. [CrossRef]

65. Kochanek, E. Regional cooperation on gas security in Central Europe. Energy Policy J. 2019, 22, 19-38. [CrossRef]

66. Ananicz, S.; Buras, P.; Smoleńska, A. Nowy Rozdziat. Transformacja Unii Europejskiej a Polska; Fundacja Batorego: Warsaw, Poland, 2021. 